Volume 27 Issue 1, Januari 2020: pp. 68-86 Copyright (C) 2020 Jurnal Hukum lus Quia lustum Faculty of Law, Universitas Islam Indonesia. ISSN 0854-8498 I e-ISSN: 2527-502X.

Open access at: http://jurnal.uii.ac.id/indek.php/IUSTUM

JH lus Quia lustum is licensed under a Creative Commons Attribution 4.0 International License. Which Permits unrestricted use, distrubution, and reproduction in any medium, provided the original work is properly cited

\title{
Hukum Pidana Sebagai Last Resort Dalam Undang-Undang Perlindungan Dan Pengelolaan Lingkungan Hidup
}

\author{
Mahrus Ali \\ Fakultas Hukum Universitas Islam Indonesia \\ Jln. Tamansiswa No. 150 Yogyakarta \\ mahrus_ali@uii.ac.id
}

Received: 15 Agustus 2019; Accepted: 16 Januari 2020; Published: 29 Juni 2020

DOI: 10.20885/iustum.vol27.iss1.art4

\begin{abstract}
This study aims to analyze the theoretical problems in placing criminal law as a last resort only on offenses in Article 100 paragraph (1) of the PPLH Law and the notion is related to the characteristics of environmental offenses. As a normative legal research, this study uses the statutory, the history, and the conceptual approaches. The results of the study concluded that the placement of criminal law as a last resort only in Article 100 paragraph (1) of the PPLH Law is theoretically problematic. The offenses in the Article, as well as the offenses in Article 101. Article 102, Article 103, Article 104, Article 107, and Article 109 (businesses/activities that are mandatory to EIA), meets the criteria for a real danger model (concrete endangerment) which requires direct contact between contaminated material and the environment carried out in an unlawful manner. Criminal law as a last resort should apply to offenses that enter the abstract endangerment model as regulated in Article 109 (businesses/activities related to UPL-UKL), Article 110, and Article 111 because they are purely administrative violations, there is no direct contact between material polluted with the environment, and protect ecological values indirectly through the provision of intervention mechanisms for the government to prevent environmental losses.
\end{abstract}

Keywords: Criminal law: last resort; concrete endangerment; abstract endangerment

Abstrak

Penelitian ini bertujuan untuk menganalisis permasalahan teoritik penempatan hukum pidana sebagai last resort hanya pada delik dalam Pasal 100 ayat (1) UU PPLH dan gagasannya dikaitkan dengan karakteristik delik lingkungan. Sebagai penelitian hukum normatif, penelitian ini menggunakan pendekatan perundang-undangan, sejarah, dan konseptual. Hasil penelitian menyimpulkan bahwa penempatan hukum pidana sebagai last resort hanya pada Pasal 100 ayat (1) UU PPLH secara teoritik bermasalah. Delik dalam pasal tersebut, sebagaimana juga delik dalam Pasal 101, Pasal 102, Pasal 103, Pasal 104, Pasal 107, dan Pasal 109 (usaha/kegiatan yang wajib amdal), memenuhi kriteria model bahaya nyata (concrete endangerment) yang mensyaratkan adanya kontak langsung antara bahan tercemar dengan lingkungan yang dilakukan secara melawan hukum. Hukum pidana sebagai last resort seharusnya berlaku pada delikdelik yang masuk ke dalam model abstract endangerment sebagaimana diatur dalam Pasal 109 (usaha/kegiatan terkait UPL-UKL), Pasal 110, dan Pasal 111 karena murni merupakan pelanggaran administrasi, tidak ada kontak langsung antara bahan tercemar dengan lingkungan, dan melindungi nilainilai ekologis secara tidak langsung melalui penyediaan mekanisme intervensi bagi pemerintah untuk mencegah timbulnya kerugian lingkungan.

Kata-kata Kunci: Hukum pidana; last resort; bahaya nyata; bahaya abstrak 


\section{Pendahuluan}

Delik-delik dalam Undang-Undang Nomor 32 Tahun 2009 tentang Perlindungan dan Pengelolaan Lingkungan Hidup (UU PPLH) sebagian besar merupakan administrative dependent crimes. ${ }^{1}$ Delik-delik dalam Pasal 100 ayat (1), ${ }^{2}$ Pasal 101, ${ }^{3}$ Pasal 102, ${ }^{4}$ Pasal 103,, ${ }^{5}$ Pasal 104,6 Pasal 109,7 dan Pasal $110^{8}$ UU PPLH bergantung sepenuhnya kepada pelanggaran terhadap persyaratan atau kewajiban administratif. Hukum pidana hanya bersifat sebagai penunjang penegakan norma di dalam hukum administrasi. Oleh karena itu, sanksi pidana ditempatkan sebagai sarana terakhir (last resort). ${ }^{9}$

Persoalannya, penempatan hukum pidana sebagai last resort justru hanya terhadap pelanggaran Pasal 100 ayat (1) mengenai pelanggaran terhadap baku mutu air limbah, baku mutu emisi, atau baku mutu gangguan. Berdasarkan ketentuan Pasal 100 ayat (2) UU PPLH, tindak pidana dalam Pasal 100 ayat (1) hanya dapat dikenakan apabila memenuhi dua syarat, yaitu; (1) sanksi administratif yang telah dijatuhkan tidak dipatuhi; dan 2) pelaku delik telah melakukan pelanggaran terhadap delik dalam Pasal 100 ayat (1) lebih dari satu kali. Ini berarti, terhadap delik-delik selain Pasal 100 ayat (1), hukum pidana ditempatkan sebagai premum remedium.

Karakteristik delik dalam Pasal 100 ayat (1) meniscayakan adanya kontak langsung antara bahan tercemar dengan lingkungan yang dilakukan secara

${ }_{1}^{1}$ Administrative dependent crimes adalah suatu perbuatan dikategorikan sebagai tindak pidana bergantung kepada pelanggaran administratif seperti pelanggaran izin atau baku mutu lingkungan. Ketiadaan dokumen izin atau surat keterangan dapat dijadikan sebagai dasar untuk menyatakan bahwa perbuatan merupakan delik. Michael Faure, Towards a New Model of Criminalization of Environmental Pollution. The Case of Indonesia", dalam Michael Faure \& Nicole Niessen (Editor), Environmental Law in Development Lesson from the Indonesian Experience, Edward Elgar Publishing Limited, UK, 2006, hlm 190-196. Grahat Nagara, "Perkembangan Sanksi Administratif dalam Penguatan Perlindungan Lingkungan terkait Eksploitasi Sumber Daya Alam (Studi Kasus: Sektor Perkebunan, Pertambangan, dan Kehutanan)", Jurnal Hukum Lingkungan, Vol. 3 2, 2017, hlm. 37

2 Setiap orang yang melanggar baku mutu air limbah, baku mutu emisi, atau baku mutu gangguan dipidana..."

3 Setiap orang yang melepaskan dan/atau mengedarkan produk rekayasa genetik ke media lingkungan hidup yang bertentangan dengan peraturan perundang-undangan atau izin lingkungan dipidana...'.

4 Setiap orang yang melakukan pengelolaan limbah B3 tanpa izin dari menteri, gubernur, atau bupati/walikota sesuai dengan kewenangannya dipidana...'

${ }^{5}$ Setiap orang yang menghasilkan limbah B3 dan tidak melakukan pengelolaan dipidana...'.

${ }^{6}$ Setiap orang yang melakukan dumping limbah dan/atau bahan ke media lingkungan hidup tanpa izin...'.

${ }^{7}$ Setiap orang yang melakukan usaha dan/atau kegiatan tanpa memiliki izin lingkungan

${ }^{8}$ Setiap orang yang menyusun amdal tanpa memiliki sertifikat kompetensi penyusun amdal dipidana...'.

9 Paul McGorrery, "The Philosophy of Criminalisation: A Review of Duff et al.'s Criminalisation Series", Criminal Law and Philosophy, 12, 2018, hlm. 199. Douglas Husak, "Applying Ultima Ratio: A Skeptical Assessment", Obio State Journal of Criminal Law, 2005, hlm. 537. Nils Jareborg, 'Criminalization as Last Resort (ultima ratio)', Obio State Journal of Criminal Law, 2005, hlm. 527-528 
melawan hukum sehingga dikategorikan ke dalam model bahaya nyata (concrete harm). ${ }^{10}$ Delik-delik dalam UU PPLH yang memiliki karakter yang sama/mirip dengan delik dalam Pasal 100 ayat (1) tercantum dalam Pasal 102, Pasal 103, dan Pasal 104. Terhadap delik-delik tersebut, pembentuk undang-undang justru menempatkan hukum pidana sebagai premum remedium. Dengan demikian, secara teoritis penempatan hukum pidana yang demikian menimbulkan masalah.

Meskipun secara teoritik bermasalah, riset-riset terdahulu justru tidak berupaya menjelaskan problem teoritis tersebut dan sekaligus menggagas bagaimana seharusnya hukum pidana ditempatkan sebagai last resort. ${ }^{11}$ Riset tersebut bahkan menyatakan bahwa 'asas ultimum remedium sudah tidak layak lagi untuk dipertahankan yaitu ketika permasalahan lingkungan telah menimbulkan dampak negatif terhadap kehidupan dan jiwa manusia'.12 Menurut peneliti, pernyataan ini tidak tepat karena delik dalam Pasal 100 ayat (1) UU PPLH dirumuskan sebagai delik formil sehingga tidak mensyaratkan adanya akibat.

\section{Rumusan Masalah}

Berdasarkan uraian pada latar belakang masalah di atas, rumusan masalah dalam penelitian ini sebagai berikut, pertama, apa permasalahan teoritik penempatan hukum pidana sebagai last resort hanya pada delik dalam Pasal 100 ayat (1) UU PPLH?; kedua, bagaimana hukum pidana seharusnya ditempatkan sebagai last resort dalam UU PPLH dikaitkan dengan karakteristik delik lingkungan?

\section{Tujuan Penelitian}

Penelitian ini bertujuan untuk mengetahui dan menganalisis permasalahan teoritik dari penempatan hukum pidana sebagai last resort hanya pada delik dalam Pasal 100 ayat (1) UU PPLH dan gagasannya dikaitkan dengan karakteristik delik lingkungan.

\footnotetext{
${ }^{10}$ Michael Faure, "The Revolution in Environmental Criminal Law in Europe", Virginia Environmental Law Journal, 35, 2017, hlm. 335

${ }^{11}$ So Woong Kim, “Kebijakan hukum pidana dalam upaya penegakan hukum lingkungan hidup”, Jurnal Dimanika Hukum, Vol 13, 2013. David Aprizone Putra, "Implikasi politik kebijakan hukum pidana dalam UUPLH”, Jurnal Legality, Vol. 25, 2017

${ }^{12}$ Lidya Suryani Widayati, "Ultimum Remedium dalam Bidang Lingkungan Hidup", Jurnal Hukum Ius Quia Iustum, Vol 22, 2015, hlm. 1
} 


\section{Metode Penelitian}

Penelitian ini merupakan penelitian hukum normatif karena yang dikaji adalah asas dan norma hukum dalam sistem perundang-undangan. Pendekatan yang digunakan adalah pendekatan sejarah, konseptual, dan perundangundangan. ${ }^{13}$ Pendekatan sejarah dibatasi kepada sejarah pembentuk UU PPLH melalui pembacaan terhadap Risalah Sidang UU tersebut. Pendekatan perundang-undangan mengacu kepada delik-delik dalam Pasal 98 hingga Pasal 115 UU PPLH. Pendekatan konseptual berkaitan dengan karakteristik delik lingkungan dan hukum pidana sebagai last resort.

Bahan hukum dalam penelitian ini berupa bahan hukum primer dan sekunder. Bahan hukum primer adalah UU PPLH terutama rumusan delik yang diatur mulai Pasal 98 hingga Pasal 115, sedangkan bahan hukum sekunder berupa Risalah Sidang UU PPLH dan literatur yang secara khusus berbicara tentang karakteristik hukum pidana lingkungan dan hukum pidana sebagai last resort.

Bahan hukum dalam penelitian ini dikumpulkan melalui studi literatur dan studi dokumen. Bahan hukum tersebut kemudian dianalisis secara deskriptif kualitatif melalui tiga alur kegiatan yang terjadi secara bersamaan yaitu reduksi bahan hukum, penyajian bahan hukum, dan penarikan kesimpulan. ${ }^{14}$ Reduksi bahan hukum dalam penelitian ini terkait penyederhanaan karakterisik delik dalam Pasal 98 hingga Pasal 115 UU PPLH. Setelah diketahui karakteristik deliknya, kemudian dilakukan pemetaan delik tersebut dikaitkan dengan fungsionalisasi hukum pidana sebagai last resort.

\section{Hasil Penelitian dan Pembahasan}

\section{Problem Teoritis Penempatan Hukum Pidana sebagai Last Resort Hanya pada Delik dalam Pasal 100 ayat (1) UU PPLH}

Takdir Rahmadi mengatakan bahwa 'materi yang diatur dalam UU PPLH mengandung segi-segi hukum perdata, hukum administrasi negara, dan hukum lingkungan'.15 Realitas yang demikian berimplikasi pada karakteristik yang menonjol pada tindak pidana lingkungan yang meniscayakan keterjalinan antara

\footnotetext{
${ }^{13}$ Johny Ibrahim, Teori dan Metodologi Penelitian Hukum Normatif, Bayu Media Publishing, Malang, 2006, hlm. 320

${ }^{14}$ Matthew B. Miles dan A. Michael Huberman, Analisis Data Kualitatif, tanpa Penerbit, tt, hlm. 16-20

15 Takdir Rahmadi, Hukum Lingkungan di Indonesia, Cet. Ketiga, Rajawali Press, Jakarta, 2013, hlm. 28-29
} 
hukum administrasi dan hukum pidana. ${ }^{16}$ Pemahaman tentang hukum pidana lingkungan mensyaratkan dua bidang ilmu sekaligus, yaitu hukum pidana dan hukum lingkungan.

Kebanyakan delik dalam UU PPLH dicirikan dengan adanya ketergantungan administratif hukum pidana (administrative dependent crime) seperti pelanggaran terhadap izin sehingga bergantung kepada pemenuhan persyaratan yang ditetapkan oleh atau ketentuan yang terkandung dalam peraturan administratif. ${ }^{17}$ Delik-delik yang keberadaannya bergantung kepada peraturan administratif dalam UU PPLH sebagai berikut:

a. Melanggar baku mutu air limbah, baku mutu emisi, atau baku mutu gangguan (Pasal 100 ayat (1));

b. Melepaskan dan/atau mengedarkan produk rekayasa genetik ke media lingkungan hidup yang bertentangan dengan peraturan perundang-undangan atau izin lingkungan (Pasal 101);

c. Melakukan pengelolaan limbah B3 tanpa izin dari Menteri, gubernur, atau bupati/walikota sesuai dengan kewenangannya (Pasal 102);

d. Menghasilkan limbah B3 dan tidak melakukan pengelolaan (Pasal 103);

e. Melakukan dumping limbah dan/atau bahan ke media lingkungan hidup tanpa izin (Pasal 104);

f. Memasukkan B3 yang dilarang menurut peraturan perundang-undangan ke dalam wilayah Negara Kesatuan Republik Indonesia (Pasal 107);

g. Melakukan usaha dan/atau kegiatan tanpa memiliki izin lingkungan (Pasal 109);

h. Menyusun amdal tanpa memiliki sertifikat kompetensi penyusun amdal (Pasal 110);

i. Menerbitkan izin lingkungan tanpa dilengkapi dengan amdal atau UKL-UPL (Pasal 111 ayat (1));

j. Menerbitkan izin usaha dan/atau kegiatan tanpa dilengkapi dengan izin lingkungan (Pasal 111 ayat (2)); dan

16 Michael G. Faure, Ingeborg M. Koopmans, Johannes C. Oudijk, "Imposing Criminal Liability on Government Officials under Environmental Law: A Legal and Economic Analysis",Loyola of Los Angeles International and Comparative Law Journal, 18, 1996, hlm. 558

17 D. Schaffmeister, "Perlindungan Hukum Pidana atas Obyek-obyek Lingkungan Hidup" dalam D. Schaffmeister, dkk, Kekhawatiran Masa Kini Pemikiran Mengenai Hukum Pidana Lingkungan dalam Teori \& Praktik, Diterjemahkan oleh Tristan P. Moeliono, PT. Citra Aditya Bakti, Bandung, 1994, hlm. 159 
k. Dengan sengaja tidak melakukan pengawasan terhadap ketaatan penanggung jawab usaha dan/atau kegiatan terhadap peraturan perundang-undangan dan izin lingkungan yang mengakibatkan terjadinya pencemaran dan/atau kerusakan lingkungan yang mengakibatkan hilangnya nyawa manusia (Pasal 112).

Delik-delik tersebut dikategorikan sebagai administrative dependent crimes karena 3 alasan. Pertama, delik-delik tersebut merupakan delik formil yang sasarannya adalah pada dilakukannya perbuatan yang dilarang, dan bukan pada akibatnya. Kedua, perbuatan yang dilarang bukan karena sifatnya yang tercela, melainkan karena dilarang oleh undang-undang (legally wrong). Ketiga, esensi delik dalam pasal-pasal tersebut berkaitan dengan pelanggaran terhadap izin sehingga nuansa administratifnya lebih kental. Seseorang diwajibkan untuk memenuhi persyaratan-persyaratan tertentu agar bisa melakukan tindakan tertentu. Pelanggaran terhadap persyaratan ini dikategorikan sebagai tindak pidana. ${ }^{18}$

Terhadap delik-delik tersebut, UU PPLH menegaskan bahwa fungsionalisasi hukum pidana sebagai last resort hanya berlaku pada pelanggaran Pasal 100 ayat (1). Ketentuan tentang eksistensi hukum pidana sebagai last resort awalnya tidak tercantum dalam Rancangan Undang-Undang tentang Perlindungan Lingkungan Hidup (RUU PLH) yang disusun oleh DPR. Prayekti dari Indonesian Center for Environmental Law (ICEL) dalam Rapat Dengar Pendapat Umum 13 Juli 2009 mengusulkan agar asas subsidiaritas perlu diperjelas. Selama ini bila ada sengketa lingkungan, hakim dan advokat seringkali bersembunyi di balik asas tersebut. Penuntut umum tidak boleh mengajukan tuntutan pidana apabila belum dilakukan penegakan hukum administrasi atau perdata terlebih dahulu. Penggunaan asas subsidiaritas dalam kasus-kasus lingkungan yang besar tidak mungkin bisa dilakukan karena apabila menunggu proses penegakan hukum administrasi atau perdata, korban sudah banyak yang meninggal atau lingkungan hidup sudah tidak mungkin terselamatkan lagi. Asas subsidiaritas perlu dikecualikan dalam kasus-kasus tertentu. ${ }^{19}$

18 Federico Picinali, "The Denial of Procedural Safeguards in Trials for Regulatory Offences: A Justification", Criminal Law and Philosophy, 11, 2017, hlm. 685

${ }_{19}$ Rapat Dengar Pendapat Umum (RDPU) dengan dengan Direktur Eksekutif Greenomics Indonesia, Direktur Forest WWF Indonesia, Direktur Eksekutif Indonesia Center Environmental, Direktur Eksekutif Nasional Wahana Lingkungan Hidup, Ketua Jaringan Advokasi Tambang, Direktur Eksekutif Keanekaragaman 
Berdasarkan pemikiran Prayekti tersebut, fungsionalisasi hukum pidana sebagai last resort sebenarnya berlaku untuk delik-delik lingkungan yang dirumuskan secara formil, dan tidak dibatasi hanya pada pelanggaran terhadap delik dalam Pasal 100 ayat (1). Argumen ini diperkuat dengan poin 5 penjelasan umum UU PPLH yang menyatakan sebagai berikut:

Upaya preventif dalam rangka pengendalian dampak lingkungan hidup perlu dilaksanakan dengan mendayagunakan secara maksimal instrumen pengawasan dan perizinan. Dalam hal pencemaran dan kerusakan lingkungan hidup sudah terjadi, perlu dilakukan upaya represif berupa penegakan hukum yang efektif, konsekuen, dan konsisten terhadap pencemaran dan kerusakan lingkungan hidup yang sudah terjadi.

UU PPLH membagi penyelesaian perkara lingkungan hidup melalui cara preventif dan represif. Cara preventif terkait pengendalian dampak lingkungan hidup dengan mendayagunakan secara maksimal instrumen pengawasan dan perizinan. Hukum pidana perlu difungsikan sebagai pelengkap mekanisme penyelesaian perkara lingkungan seperti hukum administrasi, hukum perdata, atau alternatif penyelesaian sengketa di luar pengadilan, khusus bagi delik-delik lingkungan yang dirumuskan secara formil. Pembatasan penerapan hukum pidana sebagai last resort hanya terbatas pada pelanggaran delik dalam Pasal 100 ayat (1) tentu bertentangan dengan penjelasan umum poin 5 di atas. Cara represif melalui penegakan hukum dilakukan terkait terjadinya atau timbulnya pencemaran atau kerusakan lingkungan hidup. Fungsi hukum pidana sebagai last resort dalam konteks tersebut memang tidak berlaku apabila delik lingkungan dirumuskan secara meteriil.

Penggunaan hukum pidana terhadap delik-delik dalam UU PPLH yang dikategorikan sebagai administrative dependent crimes tetap harus difungsikan sebagai last resort karena substansi sebenarnya merupakan pelanggaran terhadap persyaratan atau kewajiban administratif. Alasannya, selain tidak terdapat perdebatan dan alasan yang muncul dalam risalah sidang RUU mengenai penerapan last resort yang hanya dibatasi pada delik dalam Pasal 100 ayat (1), penempatan hukum pidana sebagai last resort juga bertentangan dengan penjelasan 
umum poin 5 UU PPLH. Selain itu, pelanggarannya belum menimbulkan kerugian apapun, dan secara substantif perbuatan yang dilarang merupakan pelanggaran administratif. Hukum pidana bersifat komplementer, dalam arti hukum pidana difungsikan untuk menanggulangi delik lingkungan apabila penyelesaian perkara lingkungan secara administratif, perdata, dan alternatif penyelesaian sengketa di luar pengadilan belum mampu menyelesaikannya.

Penempatan fungsionalisasi hukum pidana sebagai last resort hanya kepada pelanggaran Pasal 100 ayat (1) UU PPLH menimbulkan paling tidak 2 persoalan teoritik. Pertama, delik dalam Pasal 100 ayat (1) mensyaratkan adanya kontak langsung antara bahan tercemar dengan lingkungan yang dilakukan secara melawan hukum sebagai ciri dari model kriminalisasi berbasis bahaya nyata (concrete endangerment). Delik-delik model ini tidak mensyaratkan kerugian lingkungan secara nyata, tapi cukup pada pembuktian adanya ancaman kerugian dan perbuatan dilakukan secara melawan hukum. ${ }^{20}$ Tujuannya adalah untuk mencegah timbulnya kerugian baik pada manusia maupun lingkungan. ${ }^{21}$

Model kriminalisasi berbasis concrete endangerment menekankan pada 2 hal, (1) bahwa emisi atau polusi dapat menyebabkan ancaman kerugian dan itu perlu dibuktikan; dan (2) emisi atau polusi itu dilakukan secara melawan hukum. Sepanjang aturan-aturan administrasi diikuti, serta dilakukan secara sah maka perbuatan yang tergolong kategori ini tidak dianggap sebagai tindak pidana. Perbuatan tersebut dikategorikan sebagai tindak pidana apabila dilakukan secara melawan hukum dan dapat menyebabkan timbulnya ancaman bahaya..22 Model ini sebenarnya melindungi nilai-nilai ekologis secara langsung, tapi keberadaannya tetap bergantung kepada peraturan-peraturan administrasi, ${ }^{23}$ dalam arti model ini masih menggantungkan sepenuhnya kepada prosedur administrasi untuk menetapkan suatu tindak pidana. Contoh tindak pidana dalam model ini adalah larangan bagi setiap orang yang secara tidak sah membuang limbah ke air

\footnotetext{
${ }^{20}$ Michael Faure, Towards a New Model...Op.Cit., hlm. 197

21 Zachary Hoskins, "Criminalization and the Collateral Consequences of Conviction", Criminal Law and Philosophy, 12, 2018, hlm. 634

${ }^{22}$ Michael Faure, “The Revolutionin Environmental...”, Op.Cit., hlm. 335

23 Byung-Sun Cho, "Emergence of an International Environmental Criminal Law?",UCLA Journal of Environmental Law and Policy, 19, 2000/2001, hlm. 22-23
} 
permukaan, tanah atau laut yang perbuatan atau reaksinya menyebabkan kerugian, meskipun sementara, terhadap fauna.

Delik-delik dalam UU PPLH yang memiliki karakter sama dengan delik dalam Pasal 100 ayat (1) diatur dalam Pasal 101 berupa melepaskan dan/atau mengedarkan produk rekayasa genetik ke media lingkungan hidup yang bertentangan dengan peraturan perundang-undangan atau izin lingkungan, Pasal 102 berupa melakukan pengelolaan limbah B3 tanpa izin dari menteri, gubernur, atau bupati/walikota sesuai dengan kewenangannya, Pasal 103 berupa menghasilkan limbah B3 dan tidak melakukan pengelolaan, Pasal 104 berupa melakukan dumping limbah dan/atau bahan ke media lingkungan hidup tanpa izin, Pasal 107 berupa memasukkan B3 yang dilarang menurut peraturan perundang - undangan ke dalam wilayah Negara Kesatuan Republik Indonesia, dan Pasal 109 berupa melakukan usaha dan/atau kegiatan yang wajib amdal tanpa memiliki izin lingkungan.

Esensi dari delik-delik tersebut memenuhi kriteria model kriminalisasi berbasis bahaya nyata karena ada kontak antara bahan tercemar dengan lingkungan. Perbuatan tersebut juga mengancam kerusakan/pencemaran lingkungan, dan dilakukan secara melawan hukum dalam bentuk tanpa izin atau melanggar peraturan atau kewajiban administrasi. ${ }^{24}$ Secara teoritik, penempatan hukum pidana sebagai last resort pada pelanggaran Pasal 100 ayat (1) oleh pembentuk undang-undang justru bermasalah karena delik yang memiliki karakter yang sama dengan delik pasal tersebut ditemukan juga dalam beberapa pasal dalam UU PPLH. Jika konsisten, mengapa pembentuk undang-undang juga tidak menempatkan hukum pidana sebagai last resort kepada pelanggaran pasalpasal lain yang memiliki karakter yang sama dengan Pasal 100 ayat (1)?.

Kedua, dalam UU PPLH terdapat beberapa delik yang substansinya lebih ringan daripada delik dalam Pasal 100 ayat (1) seperti melakukan usaha dan/atau kegiatan (UKL-UPL) tanpa memiliki izin lingkungan dalam Pasal 109,25 menyusun

${ }^{24}$ Susan F. Mandiberg \& Michael G. Faure, "A Graduated Punishment Approach to Environmental Crimes: Beyond Vindication of Administrative Authority in the United States and Europe", Columbia Journal of Environmental Law, 34, 2009, hlm. 1196

${ }^{25}$ Delik dalam Pasal 109 Undang-Undang Nomor 32 Tahun 2009 tentang Perlindungan dan Pengelolaan Lingkungan Hidup ini terkait dengan Pasal 36 ayat (1) Undang-Undang Nomor 32 Tahun 2009 tentang Perlindungan dan Pengelolaan Lingkungan Hidup yang substansinya mengatur 2 (dua) kategori usaha dan/atau kegiatan yang wajib memiliki izin lingkungan, yaitu (1) kategori usaha dan/atau kegiatan yang wajib memiliki amdal (tergolong model concrete endangerment); (2) kategori usaha dan/atau kegiatan yang cukup memiliki UKL- 
amdal tanpa memiliki sertifikat kompetensi penyusun amdal dalam Pasal 110, dan menerbitkan izin lingkungan tanpa dilengkapi dengan UKL-UPL atau menerbitkan izin usaha dan/atau kegiatan tanpa dilengkapi dengan izin lingkungan (Pasal 111). Esensi dari delik-delik pada ketiga pasal dalam UU PPLH tersebut sebenarnya berkaitan dengan pelanggaran terhadap kewajiban-kewajiban administrasi atau pelanggaran izin, tidak mengancam terhadap kerusakan/pencemaran lingkungan, dan tidak melibatkan emisi atau pelepasan limbah karena tidak melibatkan kontak langsung antara bahan tercemar dengan lingkungan.

Pembentuk undang-undang seharusnya memfungsikan hukum pidana sebagai last resort pada delik-delik tersebut, dan bukan justru memberlakukan hukum pidana sebagai premum remidium karena delik-delik tersebut sebenarnya hanya merupakan pelanggaran administratif. Secara teoritik, sanksi pidana yang diancamkan terhadap pelanggaran administratif yang tidak melibatkan kontak langsung antara bahan tercemar dengan lingkungan bertujuan untuk memperkuat sanksi administratif. ${ }^{26}$ Peranan sanksi pidana merupakan mercenarysanction. ${ }^{27}$ Keterlibatan hukum pidana ke dalam pelanggaran administratif hanya bersifat komplementer karena eksistensinya hanya sebagai penunjang penegakan norma yang ada di bidang hukum administrasi. ${ }^{28}$ Oleh karena itu, bermasalah bila asas last resort (ultimum remedium) hanya berlaku kepada pelanggaran delik dalam Pasal 100 ayat (1) UU PPLH.

\section{Gagasan Hukum Pidana sebagai Last Resort dalam UU PPLH Dikaitkan dengan Karakteristik Delik Lingkungan}

Fungsionalisasi hukum pidana sebagai last resort dalam UU PPLH agar tidak menimbulkan problem teoritis seharusnya dikaitkan dengan karakteristik delik lingkungan. Terhadap delik-delik lingkungan dalam UU PPLH yang dikategorikan sebagai administrative independent crimes, hukum pidana perlu ditempatkan sebagai premum remedium. Alasannya adalah karena delik-delik

UPL (tergolong model abstract endangerment). Secara teoritik, keduanya memiliki karakteristik yang berbeda, sayangnya pembentuk undang-undang justru menyamakan ancaman pidananya. hlm. 42

${ }^{26}$ Muladi, Kapita Selekta Sistem Peradilan Pidana, Badan Penerbit Universitas Diponegoro, Semarang, 1995 ,

${ }^{27}$ Susan F. Mandiberg \& Michael G. Faure, "A Graduated Punishment...”, Op.Cit., hlm. 39

${ }_{28}$ Muladi, Proyeksi Hukum Pidana Materiil Indonesia di Masa Mendatang", Pidato Pengukuban Guru Besar Ilmu Hukum Pidna, Fakultas Hukum Universitas Diponegoro, Semarang, 24 Pebruari, 1990, hlm. 7 
tersebut sudah melepaskan diri sepenuhnya dari ketergantungan administratif hukum pidana yang ditandai dengan dua cara. Pertama, eliminasi izin sebagai pelindung. Seseorang sekalipun telah memiliki izin dari pejabat administrasi, jika perbuatannya menimbulkan kerugian serius terhadap lingkungan, maka perbuatan tersebut tetap dikategorikan sebagai tindak pidana. Kedua, eliminasi sifat melawan hukum sebagai elemen tindak pidana lingkungan. Hukum pidana tetap dapat digunakan apabila menimbulkan kerugian sangat serius sekalipun perbuatan tidak melawan hukum, dalam arti dilakukan sesuai dengan persyaratan izin atau peraturan administratif. ${ }^{29}$

Delik-delik yang digolongkan sebagai administrative independent crimes dalam UU PPLH sebagai berikut:

a. Dengan sengaja melakukan perbuatan yang mengakibatkan dilampauinya baku mutu udara ambien, baku mutu air, baku mutu air laut, atau kriteria baku kerusakan lingkungan hidup (Pasal 98 ayat (1));

b. Dengan sengaja melakukan perbuatan yang mengakibatkan dilampauinya baku mutu udara ambien, baku mutu air, baku mutu air laut, atau kriteria baku kerusakan lingkungan hidup yang mengakibatkan orang luka dan/atau bahaya kesehatan manusia (Pasal 98 ayat (2));

c. Dengan sengaja melakukan perbuatan yang mengakibatkan dilampauinya baku mutu udara ambien, baku mutu air, baku mutu air laut, atau kriteria baku kerusakan lingkungan hidup yang mengakibatkan orangmengalami luka berat atau mati (Pasal 98 ayat (3));

d. Karena kelalainnya melakukan perbuatan yang mengakibatkan dilampauinya baku mutu udara ambien, baku mutu air, baku mutu air laut, atau kriteria baku kerusakan lingkungan hidup (Pasal 99 ayat (1));

e. Karena kelalainnya melakukan perbuatan yang mengakibatkan dilampauinya baku mutu udara ambien, baku mutu air, baku mutu air laut, atau kriteria baku kerusakan lingkungan hidup yang mengakibatkan orang luka dan/atau bahaya kesehatan manusia (Pasal 99 ayat (2));

f. Karena kelalainnya melakukan perbuatan yang mengakibatkan dilampauinya baku mutu udara ambien, baku mutu air, baku mutu air laut, atau kriteria

${ }^{29}$ Susan F. Mandiberg \& Michael G. Faure, "A Graduate Punishment...”, Op. Cit., hlm. 481-485 
baku kerusakan lingkungan hidup yang mengakibatkan orang mengalami luka berat atau mati (Pasal 99 ayat (3));

g. Memasukkan limbah ke dalam wilayah Negara Kesatuan Republik Indonesia yang berasal dari luar wilayah Negara Kesatuan Republik Indonesia ke media lingkungan hidup Negara Kesatuan Republik Indonesia (Pasal 105);

h. Memasukkan Limbah Bahan Berbahaya dan Beracun (B3) ke dalam wilayah Negara Kesatuan Republik Indonesia (Pasal 106);

i. Melakukan pembakaran lahan (Pasal 108);

j. Memberikan informasi palsu, menyesatkan, menghilangkan informasi, merusak informasi, atau memberikan keterangan yang tidak benar yang diperlukan dalam kaitannya dengan pengawasan dan penegakan hukum yang berkaitan dengan perlindungan dan pengelolaan lingkungan hidup (Pasal 113); dan

k. Sengaja mencegah, menghalang-halangi, atau menggagalkan pelaksanaan tugas pejabat pengawas lingkungan hidup dan/atau pejabat penyidik pegawai negeri sipil (Pasal 115).

Delik-delik dalam Pasal 98, Pasal 99, Pasal 105, Pasal 106, dan Pasal 108 tersebut merupakan delik yang tidak bergantung kepada pelanggaran administratif karena menimbulkan atau dapat menimbulkan pencemaran atau kerusakan terhadap lingkungan hidup yang berbahaya baik bagi kelangsungan hidup manusia maupun lingkungan hidup. Delik-delik tersebut lebih memiliki nuansa perlindungan terhadap daya dukung dan daya tampung lingkungan. ${ }^{30}$ Delik-delik dalam Pasal 113 dan Pasal 115 merupakan perbuatan tercela secara moral. Perbuatan tersebut sekalipun tidak dilarang oleh UU, perbuatan tersebut tetap tercela secara moral dan bertentangan dengan nilai-nilai yang ada dalam masyarakat (morally wrong).

Asas last resort dalam UU PPLH seharusnya hanya berlaku kepada delikdelik lingkungan yang dikategorikan sebagai administrative dependent crimes sebagaimana tercermin dalam model kriminalisasi berbasis bahaya abstrak (abstract endangerment), model bahaya nyata (concrete endangerment), dan kerugian

30 Syahrul Machmud, Problematika Penerapan Delik Formil dalam Perspektif Penegakan Hukum Pidana Lingkungan di Indonesia Fungsionalisasi Azas Ultimum remedium sebagai Pengganti Azas Subsidiaritas, Mandar Maju, Bandung, 2012, hlm. 243 
nyata (concrete harm). Model abstract endangerment mengkriminalisasi kerusakan/pencemaran lingkungan secara tidak langsung. Hukum pidana membatasi pada penegakan hukum administrasi yang telah ada sebelumnya. Kriminalisasi menurut model ini hanya ditujukan kepada pelanggaran terhadap kewajiban-kewajiban administrasi. ${ }^{31}$ Model ini dibatasi hanya pada tindak pidana-tindak pidana yang tidak melibatkan kontak langsung antara bahan tercemar dengan lingkungan. ${ }^{32}$

Tindak pidana-tindak pidana dalam UU PPLH yang masuk dalam model abstractendangerment berupa: : a) melakukan usaha dan/atau kegiatan (UKL-UPL) tanpa memiliki izin lingkungan (Pasal 109); c) menyusun amdal tanpa memiliki sertifikat kompetensi penyusun amdal (Pasal 110); dan d) menerbitkan izin lingkungan tanpa dilengkapi dengan UKL-UPL atau menerbitkan izin usaha dan/atau kegiatan tanpa dilengkapi dengan izin lingkungan (Pasal 111). Esensi dari delik-delik pada ketiga pasal dalam UU PPLH tersebut sebenarnya berkaitan dengan pelanggaran terhadap kewajiban-kewajiban administrasi atau pelanggaran izin, tidak mengancam terhadap kerusakan/pencemaran lingkungan, dan tidak melibatkan emisi atau pelepasan limbah. Perbuatan tersebut tidak melibatkan kontak langsung antara bahan tercemar dengan lingkungan.

Model concrete endangerment tidak mensyaratkan bahwa kerugian nyata harus dibuktikan, tapi cukup pada pembuktian adanya ancaman kerugian dan perbuatan dilakukan secara melawan hukum. ${ }^{33}$ Model ini juga melindungi nilainilai ekologis secara langsung, meskipun keberadaannya tetap bergantung kepada peraturan-peraturan administrasi. ${ }^{34}$ Bentuk-bentuk tindak pidana dalam UU PPLH yang masuk ke dalam model concrete endangerment, yaitu; a) melepaskan dan/atau mengedarkan produk rekayasa genetik ke media lingkungan hidup yang bertentangan dengan izin lingkungan (Pasal 101); b)

${ }_{31}$ M. Faure \& M. Nisser, "How to Punish Environmental Pollution- Some Reflections on the Various Models of Criminalization of Environmental Harm", European Journal of Crime, Criminal Law and Criminal Justice, 3 , 1995, hlm. 319. Michael Faure, "The Revolutionin Environmental...”, Op.Cit., 2017, hlm. 334

32 Susan F. Mandiberg \& Michael G. Faure, “A Graduated Punishment...”, Op.Cit., hlm. 454-455

33 Michael Faure, Towards a New Model..., Op.Cit., hlm. 197. Michael Faure, "The Revolutionin Environmental..", Op.Cit, hlm. 335. Victor Flatt, "Will the Means Justify the End of Environmental Law? Environmental Law Must Undergo Reasoned Legislative Debate", Arizona Journal of Environemtanl Law \& Policy, 9, 2019, hlm. 130

${ }^{34}$ Byung-Sun Cho, “Emergence of an...”, Op.Cit., hlm. 22-23 
melanggar baku mutu air limbah, baku mutu emisi, atau baku mutu gangguan (Pasal 100); c) melakukan pengelolaan limbah B3 tanpa izin (Pasal 102); d) menghasilkan limbah B3 dan tidak melakukan pengelolaan (Pasal 103); e) melakukan dumping limbah dan/atau bahan ke media lingkungan hidup tanpa izin (Pasal 104); dan melakukan usaha/kegiatan yang wajib amdal (Pasal 109). Esensi dari tindak pidana-tindak pidana tersebut memenuhi kriteria model kriminalisasi berbasis concrete endangerment karena ada kontak antara bahan tercemar dengan lingkungan. Perbuatan tersebut juga mengancam kerusakan/pencemaran lingkungan, dan dilakukan secara melawan hukum dalam bentuk tanpa izin atau melanggar peraturan atau kewajiban administrasi. ${ }^{35}$

Model concrete harm mensyaratkan bahwa kerugian lingkungan harus berupa kerugian lingkungan secara nyata, ${ }^{36}$ seperti kerugian aktual bagi manusia, lingkungan, bahkan generasi mendatang37 meskipun hukum pidana belum melepaskan diri dari ketergantungan administratif. Model ini meniscayakan pembuktian sebab akibat yang dalam hukum pidana. Tindak pidana dalam UU PPLH yang masuk ke dalam model kriminalisasi berbasis concrete harm diatur dalam Pasal 112 yaitu, pejabat berwenang yang dengan sengaja tidak melakukan pengawasan terhadap ketaatan penanggung jawab usaha dan/atau kegiatan terhadap peraturan perundang-undangan dan izin lingkungan yang mengakibatkan terjadinya pencemaran dan/atau kerusakan lingkungan yang mengakibatkan hilangnya nyawa manusia. Pasal ini mensyaratkan adanya kerugian aktual pencemaran dan/atau kerusakan lingkungan dan hilangnya nyawa manusia, tapi keberadaannya tetap masih berupa ketergantung administratif hukum pidana. Frasa ...terhadap peraturan perundang-undangan dan izin lingkungan... membuktikan hal itu.

35 Susan F. Mandiberg, "Locating the Environmental Harm in Environmental Crimes", Utah Law Review, 2009, hlm. 1196

${ }^{36}$ Susan F. Mandiberg \& Michael G. Faure, “A Graduated Punishment...”, Op.Cit.,hlm. 469

37 Eileen Skinnider, Victims of Environmental Crimes - Mapping the Issues, The International Center for Criminal Law Reform and Criminal Justice Policy, Canada, 2011, hlm. 31-43. Sumudu Atapattu, "Climate Change, International Environmental Law Principles, and the North-South Divide", Transnational Law \& Contemporary Problems, 26, 2017, hlm. 254-255. Thomas M. Antkowiak, "A Dark Side of Virtue: The InterAmerican Court and Reparations for Indigenous Peoples", Duke Journal of Comparative \& International Law, 25, 2014, hlm. 127-128 
Berdasarkan uraian di atas, delik-delik pada ketiga model tersebut sebenarnya masih belum melepaskan diri dari ketergantungan administratif hukum pidana, meskipun gradasi seriusitas deliknya berbeda. Delik-delik yang masuk ke dalam model abstract endangerment merupakan delik yang paling ringan karena murni merupakan pelanggaran administrasi, tidak ada kontak langsung antara bahan tercemar dengan lingkungan, dan melindungi nilai-nilai ekologis secara tidak langsung melalui penyediaan mekanisme intervensi bagi pemerintah untuk mencegah timbulnya kerugian lingkungan. ${ }^{38}$

Hukum pidana dalam konteks ini perlu ditempatkan sebagai last resort yang dilengkapi dengan pengaturan tentang ketentuan hukum acaranya. Jika tindak pidana dilakukan pertama kali, maka hukum pidana ditempatkan sebagai last resort. Jika tindak pidana dilakukan kedua kali atau apabila proses penyidikan, penuntutan, atau persidangan terhadap delik-delik dalam abstract endangerment telah dilakukan atau sedang berlangsung tetapi pelaku bersedia membayar jumlah maksimal denda sebagaimana pasal yang dilanggar, maka hukum pidana juga ditempatkan sebagai last resort. Akan tetapi, jika hal-hal tersebut tidak dipenuhi pelaku, maka hukum pidana ditempatkan sebagai premum remedium.

Terhadap delik-delik dalam concrete endangerment dan concrete harm, hukum pidana tetap perlu ditempatkan sebagai premum remedium. Tujuannya adalah untuk mencegah timbulnya kerugian baik berupa kerusakan dan/atau pencemaran lingkungan maupun kesehatan, keselamatan atau harta benda manusia. ${ }^{39}$ Kerugian lingkungan secara spesifik berupa (ancaman) kerusakan dan degradasi ekosistem, kepunahan spesies, perubahan cuaca dan pemanasan global, pencemaran lingkungan, dan kerugian terhadap binatang.40 Korban tindak pidana lingkungan juga tidak dapat dihitung dan jaraknya bisa terjadi puluhan tahun kemudian sejak tindak pidana pertama dilakukan. Bahan berbahaya dan beracun yang dibuang ke udara tanpa melalui prosedur dan proses yang aman bagi lingkungan meningkatkan timbulnya penyakit pernafasan dan mengurangi kualitas keseluruhan atmosfer bumi, dan ini dapat saja dirasakan jauh setelah

${ }^{38}$ Ibid., hlm. 496-497

${ }^{39}$ Ibid., hlm. 497-498

40 Jan G. Laitos, "Standing and Environmenal Harm: The Double Paradox", Virginia Environmental Law Journal, 31, 2013, hlm. 67-71 
pelaku membuang bahan tersebut. ${ }^{41}$ Delik lingkungan juga ditandai dengan sifatnya yang ada dimana-mana, dalam arti lokasi terjadinya delik dan lokasi timbulnya kerugian berbeda (principle ofubiquity). ${ }^{42}$

\section{Penutup}

Berdasarkan risalah sidang RUU PPLH, penempatan hukum pidana sebagai last resort berlaku untuk delik-delik lingkungan yang dirumuskan secara formil. Pembatasan fungsionalisasi hukum pidana sebagai last resort yang hanya pada pelanggaran delik dalam Pasal 100 ayat (1) justru menimbulkan persoalan teoritik. Esensi delik dalam Pasal 100 ayat (1) mensyaratkan adanya kontak langsung antara bahan tercemar dengan lingkungan yang dilakukan secara melawan hukum sebagai ciri dari model kriminalisasi berbasis bahaya nyata (concrete endangerment). Delik-delik dalam UU PPLH yang memiliki karakter sama dengan delik dalam Pasal 100 ayat (1) diatur dalam Pasal 101, Pasal 102, Pasal 103, Pasal 104, Pasal 107, dan Pasal 109 (kategori usaha/kegiatan yang wajib amdal). Terhadap delik-delik tersebut dan juga delik-delik dalam model kerugian nyata (concrete harm), hukum pidana seharusnya tetap perlu ditempatkan sebagai premum remedium.

Terdapat beberapa delik dalam UU PPLH yang substansinya lebih ringan daripada delik dalam Pasal 100 ayat (1) seperti dalam Pasal 109 (kategori usaha/kegiatan yang perlu UKL-UPL), Pasal 110, dan Pasal 111. Beberapa delik tersebut sebenarnya merupakan pelanggaran terhadap kewajiban-kewajiban administrasi atau pelanggaran izin, tidak mengancam terhadap kerusakan/ pencemaran lingkungan, dan tidak melibatkan kontak langsung antara bahan tercemar dengan lingkungan sebagai ciri dari model abstract endangerment. Pembentuk undang-undang seharusnya memfungsikan hukum pidana sebagai last resort pada pasal-pasal tersebut. Penelitian ini menyarankan perlunya diatur secara rinci ketentuan hukum acara tentang fungsionalisasi hukum pidana sebagai ultimum remedium dalam UU PPLH.

\footnotetext{
${ }^{41}$ Neal Shover \& Aaron S. Routhe, "Environmental Crime", Crime and Justice, 32, 2005, hlm. 323-324

${ }^{42}$ Hamdan Qudah, Towards International Criminalization of Transboundry Environmental Crimes, Dissertation, Pace Law School, New York, 2014, hlm. 71
} 


\section{Daftar Pustaka}

\section{Buku}

B. Miles, Matthew dan Huberman, A. Michael, Analisis Data Kualitatif, tanpa Penerbit, $\mathrm{tt}$.

D. Schaffmeister, et.al, Kekhawatiran Masa Kini Pemikiran Mengenai Hukum Pidana Lingkungan dalam Teori $\mathcal{E}$ Praktik, Diterjemahkan Oleh Tristan P. Moeliono, PT. Citra Aditya Bakti, Bandung, 1994.

Faure, Michael \& Niessen, Nicole (Editor), Environmental Law in Development Lesson from the Indonesian Experience, Edward Elgar Publishing Limited, UK, 2006.

Ibrahim, Johny, Teori dan Metodologi Penelitian Hukum Normatif, BayuMedia Publishing, Malang, 2006.

Machmud, Syahrul, Problematika Penerapan Delik Formil dalam Perspektif Penegakan Hukum Pidana Lingkungan di Indonesia Fungsionalisasi Azas Ultimum remedium sebagai Pengganti Azas Subsidiaritas, Mandar Maju, Bandung, 2012.

Muladi, Kapita Selekta Sistem Peradilan Pidana, Badan Penerbit Universitas Diponegoro, Semarang, 1995.

Proyeksi Hukum Pidana Materiil Indonesia di Masa Mendatang", Pidato Pengukuhan Guru Besar Ilmu Hukum Pidna, Fakultas Hukum Universitas Diponegoro, Semarang, 24 Pebruari, 1990.

Qudah, Hamdan, Towards International Criminalization of Transboundry Environmental Crimes, Dissertation, Pace Law School, New York, 2014.

Rahmadi, Takdir, Hukum Lingkungan di Indonesia, Cet. Ketiga, Rajawali Press, Jakarta, 2013.

Skinnider, Eileen, Victims of Environmental Crimes - Mapping the Issues, The International Center for Criminal Law Reform and Criminal Justice Policy, Canada, 2011.

\section{Jurnal}

Antkowiak, Thomas M.,"A Dark Side of Virtue: The Inter-American Court and Reparations for Indigenous Peoples", Duke Journal of Comparative $\mathcal{E}$ International Law, 25, 2014.

Atapattu, Sumudu, "Climate Change, International Environmental Law Principles, and the North-South Divide", Transnational Law E Contemporary Problems, 26, 2017.

Cho, Byung-Sun, "Emergence of an International Environmental Criminal Law?", UCLA Journal of Environmental Law and Policy, 19, 2000/2001.

Flatt, Victor, "Will the Means Justify the End of Environmental Law? Environmental Law Must Undergo Reasoned Legislative Debate", Arizona Journal of Environemtanl Law E Policy, 9, 2019. 
Hoskins, Zachary, "Criminalization and the Collateral Consequences of Conviction", Criminal Law and Philosophy, 12, 2018.

Husak, Douglas, "Applying Ultima Ratio: A Skeptical Assessment", Ohio State Journal of Criminal Law, 2005.

Jareborg, Nils, 'Criminalization as Last Resort (ultima ratio)', Ohio State Journal of Criminal Law, 2005.

Kim, So Woong, "Kebijakan hukum pidana dalam upaya penegakan hukum lingkungan hidup", Jurnal Dimanika Hukum, Vol 13, 2013.

"Locating the Environmental Harm in Environmental Crimes", Utah Law Review, 2009.

Laitos, Jan G., "Standing and Environmenal Harm: The Double Paradox", Virginia Environmental Law Journal, 31, 2013.

Mandiberg, Susan F., \& Michael G. Faure, "A Graduated Punishment Approach to Environmental Crimes: Beyond Vindication of Administrative Authority in the United States and Europe", Columbia Journal of Environmental Law, 34, 2009.

McGorrery, Paul, "The Philosophy of Criminalisation: A Review of Duff et al.'s Criminalisation Series", Criminal Law and Philosophy, 12, 2018.

Michael, Faure \& M. Nisser, "The Revolution in Environmental Criminal Law in Europe", Virginia Environmental Law Journal, 35, 2017.

"How to Punish Environmental Pollution- Some Reflections on the Various Models of Criminalization of Environmental Harm", European Journal of Crime, Criminal Law and Criminal Justice, 3, 1995.

Ingeborg M. Koopmans, Johannes C. Oudijk, "Imposing Criminal Liability on Government Officials Under Environmental Law: A Legal and Economic Analysis", Loyola of Los Angeles International and Comparative Law Journal, 18, 1996.

Nagara, Grahat, "Perkembangan Sanksi Administratif dalam Penguatan Perlindungan Lingkungan terkait Eksploitasi Sumber Daya Alam (Studi Kasus: Sektor Perkebunan, Pertambangan, dan Kehutanan)", Jurnal Hukum Lingkungan, Vol. 3 2, 2017.

Picinali, Federico, "The Denial of Procedural Safeguards in Trials for Regulatory Offences: A Justification", Criminal Law and Philosophy, 11, 2017.

Putra, David Aprizone, "Implikasi politik kebijakan hukum pidana dalam UUPLH", Jurnal Legality, Vol 25, 2017.

Shover, Neal, \& Aaron S. Routhe, "Environmental Crime", Crime and Justice, 32, 2005.

Widayati, Lidya Suryani, "Ultimum Remedium dalam Bidang Lingkungan Hidup", Jurnal Hukum Ius Quia Iustum, Vol 22, 2015. 


\section{Undang-Undang dan Risalah Sidang}

Undang-Undang Nomor 32 Tahun 2009 Tentang Perlindungan dan Pengelolaan Lingkungan Hidup, Lembaran Negara Republik Indonesia Tahun 2009 Nomor 140, Tambahan Lembaran Negara Republik Indonesia Nomor 5059

Rapat Dengar Pendapat Umum (RDPU) dengan dengan Direktur Eksekutif Greenomics Indonesia, Direktur Forest WWF Indonesia, Direktur Eksekutif Indonesia Center Environmental, Direktur Eksekutif Nasional Wahana Lingkungan Hidup, Ketua Jaringan Advokasi Tambang, Direktur Eksekutif Keanekaragaman Hayati Indonesia, Koordinator Eksekutif Huma dan Ketua Umum Perhimpunan Cendikiawan Lingkungan Hidup, 13 Juli 2009 